
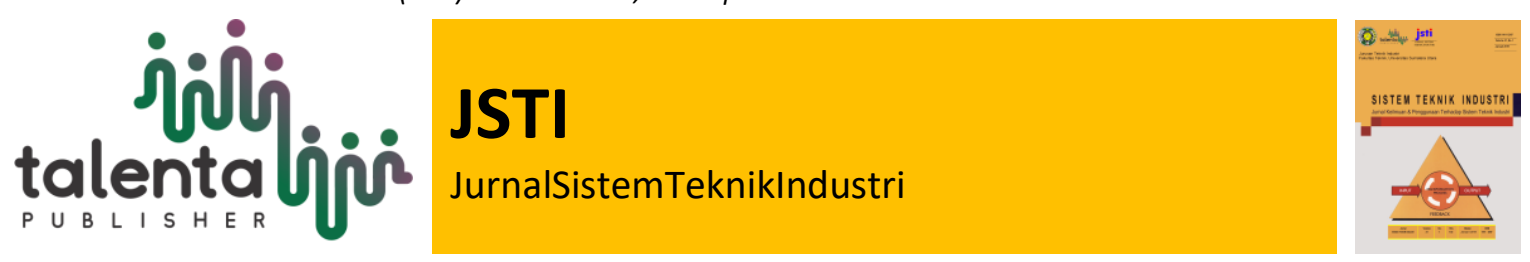

\title{
Manajemen Risiko Rantai Pasok Ikan Bandeng Kelompok Tani Tambak Bungkak dengan Integrasi Metode Analytic Network Process (ANP) dan Failure Mode and Effect Analysis (FMEA)
}

\author{
Akhmad Wasiur Rizqi, Moh. Jufriyanto \\ 1,2,Program Studi Teknik Industri, Fakultas Teknik Universitas Muhammadiyah Gresik
}

\begin{abstract}
Milkfish is a fish that has rich nutrient content. Milkfish have high protein and low fat content. One of the groups who conduct milkfish cultivation is a farmer group of Bungkak. This farmer group moves distribution of milkfish supply to collector merchants and fish processing industry. The problems that occur in the farmer group is low productivity and the supply chain risk such as price, an environment that affects the business sustainability process. The research aims to identify risks and conduct risk control of the milkfish supply chain. The methods used are ANP (Analytical Network Process) and FMEA (Failure Mode and Effect Analysis). Both methods are done integration so that acquired WRPN (Weighted risk priority number) value for the risk of improvement. The results of the study gained that the highest priority was production risk with WRPN value of 186.26. The risk control is the education of the vast fish farming land and lending to expand the land, making reservoirs for water shelter to facilitate irrigation, and and the provision of additional nutrients for fish and regulate water conditions
\end{abstract}

Keyword:Milkfish, Farmer Group, Fish Farming, supply chain risk,Analytic Network Process (ANP), Failure Mode and Effect Analysis (FMEA).

\begin{abstract}
Abstrak. Ikan bandeng merupakan ikan yang memiliki kaya akan kandungan gizi. Ikan bandeng memiliki kandungan protein yang tinggi dan rendah lemak. Salah satu kelompok yang melakukan budidaya ikan bandeng yaitu kelompok tani tambak bungkak. Kelompok tani ini bergerak penyaluran distribusi pasokan ikan bandeng ke pedagang pengumpul dan industri pengolahan ikan. Permasalahan yang terjadi pada kelompok tani tersebut yaitu produktivitas rendah serta risiko rantai pasok seperti harga, lingkungan yang berpengaruh pada proses keberlanjutan bisnisnya. Penelitian ini bertujuan untuk mengidentifikasi risikorisiko dan melakukan pengendalian risiko pada rantai pasok ikan bandeng. Metode yang digunakan adalah ANP (Analytical Network Process) dan FMEA (Failure Mode and Effect Analysis). Kedua metode tersebut dilakukan integrasi sehingga diperoleh nilai WRPN (weighted risk priority number) untuk prioritas risiko untuk dilakukan perbaikan. Hasil penelitian diperoleh bahwa prioritas tertinggi yaitu risiko produksi dengan nilai WRPN sebesar 186,26. Pengendalian risiko yang dilakukan yaitu edukasi luas lahan budidaya ikan bandeng dan pemberian pinjaman untuk memperluas lahan, pembuatan waduk untuk penampungan air untuk mempermudah pengairan, dan pemberian nutrisi tambahan untuk ikan dan mengatur kondisi air.
\end{abstract}

Kata Kunci:Ikan Bandeng, Kelompok Tani, Budidaya Ikan, Risiko Rantai Pasok, Analytic Network Process (ANP), Failure Mode and Effect Analysis (FMEA

\footnotetext{
*Corresponding author at: Program Studi Teknik Industri, Fakultas Teknik, Universitas Muhammadiyah Gresik, Jl. Sumatera No 101 Gresik Kota Baru, Gresik, Jawa Timur
} 
Received26 Mei 2020 | Revised10 Juni 2020 | Accepted17 Juni 2020

\section{Pendahuluan}

Ikan merupakan salah satu sumber bahan pangan hewani yang mempunyai kelebihan antara lain memiliki kandungan asam amino esensial yang lengkap, kandungan asam-asam lemak tidak jenuh yang sangatdibutuhkan, kandungan vitamin dan mineral yang cukup serta daya cernanya yang tinggi. Berikut merupakan konsumsi ikan masyarakat Indonesia[1] :

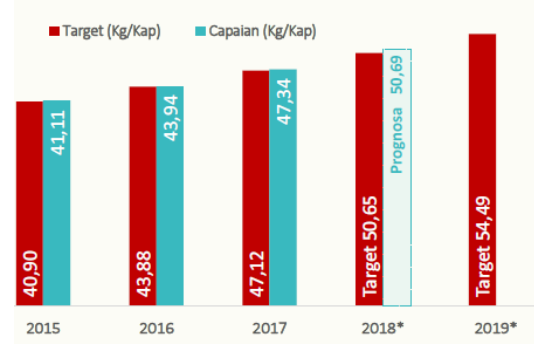

Gambar 1 Konsumsi ikan masyarakat Indonesia

Salah satu ikan yang dikonsumsi masyarakat Indonesia adalah ikan bandeng. Ikan bandeng merupakan salah satu ikan budidaya yang kaya akan kandungan gizi. dalam $100 \mathrm{~g}$ daging ikan bandeng mengandung $129 \mathrm{kkal}$ energi, $20 \mathrm{~g}$ protein, 4,8 g lemak, $150 \mathrm{mg}$ fosfor, $20 \mathrm{mg}$ kalsium, $2 \mathrm{mg}$ zat besi, $150 \mathrm{SI}$, vitamin A, dan 0,05 mg vitamin B1. Berdasarkan komposisi gizi tersebut maka ikan bandeng digolongkan sebagai ikan berprotein tinggi dan berlemak rendah[2].

Kabupaten Gresik merupakan salah satu kota yang dikenal sebagai sentra budidaya tambak di jawa timur. Rata-rata mayoritas masyarakatnya bermatapencaharian sebagai petani tambak ikan. Jenis ikan yang menjadi favorit untuk dibudidayakan adalah ikan bandeng. Salah satu pelaku budidaya tambak ikan bandeng yaitu Kelompok Tani Tambak Bungkak di Desa Banyuwangi Kecamatan Manyar Kabupaten Gresik merupakan salah satu kelompok budidaya ikan bandeng yang ada di Gresik. Kelompok ini bergerak dalam budidaya ikan bandeng serta penjualan ikan bandeng. Kelompok ini juga mengatur bagaimana hasil budidaya ikan bandeng dari seluruh anggota dapat di jual ke konsumen mulai dari pengumpul ikan hingga ke pedagang-pedagang ikan seperti industri pengolaahan ikan, serta langsung ke konsumen

Permasalahan yang terjadi, kurangnya para pelaku usaha budi daya ikan bandeng khususnya kelompok tani tidak melakukan identifikasi serta analisis risiko yang ada dalam proses bisnisnya utamanya sistem rantai pasok dari ikan bandeng tersebut. Permasalahan tersebut meliputi risiko harga yang tidak stabil, lingkungan, risiko mengenai pasar dan pasokan yang selalu mengalami perubahan. Risiko-risiko tersebut membuat terhambatnya sistem rantai pasok, karena kurangnya dilakukan suatu analisis berupa mitigasi dari risiko. Selain itu, juga berdampak pada rendahnya daya saing dan produktivitas serta mutu yang belum sesuai dengan keinginan konsumen. 
Rantai pasok adalah suatu metode dengan tujuan untuk meningkatkan daya pelayanan (serviceability) dalam menghasilkan suatu produk barang atau jasa kepada pengguna akhir dengan serangkaian proses produksi [3]. Suatu rantai pasok yang efektif merupakan salah satu perspektif yang digunakan untuk meningkatkan keunggulan kompetiti dalam menjaga keberlangsungan sebuah usaha [4].

Konsep manajemen rantai pasok merupakan suatu konsep baru yang memperlihatkan semua kegiatan perusahaan sebagai bagian yang terintegrasi. Integrasi meliputi perusahaan dalam hulu sebagai penyedia bahan baku dan integrasi dalam hilir sebagai proses distribusi dan pemasaran produk [5]. Manajemen rantai pasok yang baik yaitu perusahaan mampu menyajikan produk yang dikehendaki dengan cepat dan tepat serta sesuai dengan keinginan konsumen akhir. Suatu manajemen rantai pasok dikatankan handal, apabila mampu mengelola risiko yang ada pada rantai pasok [6].

Dalam proses proses rantai pasok tentunya ditemukana berbagai risiko yang dapat mempengaruhi alur dari proses rantai pasok sehingga menyebabkan alur tersebut tidak lancar [7]. Risiko merupakan probabilitas suatu peristiwa yang akan terjadi selama waktu tertentu dan mengakibatkan kerugian [8]. Manajemen risiko adalah suatu bidang ilmu yang membahas tentang cara organisasi dalam menerapkan ukuran untuk pemetaan berbagai permasalahan yang ada secara manajemen komprehensif dan sistematis [9].

Salah satu pendekatan dalam melakukan manajemen rantai pasok adalah manajemen risiko rantai pasok (supply chain risk management). Pendekatan ini bertujuan bagaimana pengelolaan risiko mulai dari perencanaan strategi, tujuan, sasaran, kebijakan, tindakan prosedur yang dilakukan secara terintegrasi dalam rantai pasok [6]. Pengelolaan risiko yang digabungkan dengan rantai pasok dan manajemen risiko diharapkan mampu mengurangi hambatan yang terjadi terkait dengan proses distribusi produk ke konsumen akhir sehingga suatu produk dapat berkualitas dan tepat waktu [3].

Tujuan penelitian ini yaitu mengidentifikasi risiko-risiko pada rantai pasok ikan bandeng, melakukan analisis untuk mengetahui risiko tertinggi pada masing-masing cluster yang terlibat dalam struktur rantai pasok dan juga menganalisis prioritas risiko pada rantai pasok ikan bandeng, melakukan evaluasi dan mitigasi risiko rantai pasok ikan bandeng, serta melakukan implikasi manajerial dari manajemen risiko rantai pasok ikan bandeng sebagai upaya peningkatan produktivitas kinerja dan daya saing rantai pasok ikan bandeng pada Kelompok Tani Tambak Bungkak.

Metode yang digunakan dalam penelitian ini yaitu metode Analytic Network Process (ANP) dan FMEA (Failure mode and Effect Analysis). Metode ANP memiliki kelebihan dibandingkan AHP, dimana metode ANP mampu melakukan keterkaitan antar kriteria dan juga alternatif [10]. FMEA 
merupakan suatu metode yang berfungsi untuk mengevaluasi kegagalan yang terjadi dalam sebuah sistem, desain, proses, atau pelayanan [6].

Pada penelitian sebelumnya oleh [6], tentang manajemen risiko rantai pasok tebu (studi kasus di PTPN X), dari hasil penelitian terdapat beberapa risiko yaitu risiko harga bibit, produksi, kualitas tebu, produksi dan harga gula. Prioritas tertinggi adalah pada risiko produksi. Upaya yang dilakukan adalah peningkatan manajemen usaha petani, mekanisasi tebang angkut, dan kebijakan integrase manajemen industri gula.

Penelitian tentang manajemen risiko rantai pasok agroindustri gula merah tebu di kabupaten agam, provinsi sumatera barat oleh [8]. Hasil penelitiannya, bahwa risiko produksi menjadi sumber risiko utama. Faktor OKP (operational key process) menjadi prioritas utama dalam manajemen rantai pasok dengan lebih menekankan pada perbaikan manajemen produksi. Alternatif utama dalam pengendalian risiko dengan cara melemahkan risiko yaitu melakukan perbaikan kualitas bahan baku dan teknologi pengolahan serta dukungan pemerintah dalam menjaga stabilitas harga saka.

Pada penelitian juga terdahulu tentang risiko rantai pasok kakao di Indonesia dengan metode analytic network process dan failure mode effect analysis terintegrasi oleh [11]. Tujuan dari penelitian tersebut adalah untuk mengetahui dan menganalisis risiko tertinggi dalam rantai pasokan kakao. Dari hasil penelitiannya diperoleh anggota pelaku rantai pasok dalam manajemen risiko rantai pasok kako adalah petani dan risiko dengan prioritas terbesar adalah risiko produksi. Pengendalian risiko yang dilakuka meliputi pembinaan pendampingan secara langsung perlu dilakukan oleh industri pengolahan kakao terhadap para petani, serta sosialisasi dan pengawasan penerapan standar kualitas kakao. Selain itu, dana yang terkumpul dari bea keluar dapat di share kembali ke daerah oleh pemerintah

Pada penelitian ini, metode ANP digunakan untuk mengidentifikasi risiko pada masing-masing anggota rantai pasok ikan bandeng yang diperoleh dari hasil penentuan prioritas risiko. Selain itu, hasil dari ANP juga berupa nilai bobot dari faktor risiko yang paling dominan dan berpengaruh dalam rantai pasok ikan bandeng. Metode FMEA digunakan untuk menganalisis dan evaluasi risiko, dimana hasil penilaian berupa RPN (risk priority number). Hasil kedua dari metode tersebut dilakukan suatu integrasi yang dinamakan dengan WRPN ( weighted risk priority number) yang merupakan perkalian hasil penilaian bobot ANP dengan nilai RPN dari FMEA. Hasil tersebut akan menggambarkan potensi kegagalan yang sangat serius, sehingga nilai WRPN yang tinggi maka dapat diartikan prioritas utama dalam evaluasi risiko.

\section{Tinjauan Pustaka}

\subsection{Rantai Pasok}

Rantai pasok adalah kegiatan integrasi meliputi aliran material, informasi, uang, dimana pokok bahasannya mencakup manajemen sumber daya yang dimiliki oleh suatu lembaga atau 
perseorangan untuk mencapai tujuan [12]. Rantai pasok merupakan kegiatan yang menekankan semua aktivitas untuk memenuhi kebutuhan konsumen, dalam prosesnya meliputi aliran transformasi barang mulai dari bahan baku sampai ke kinsmen akhir yang disertai dengan aliran informasi dan uang [13].

\subsection{Risiko}

Risiko merupakan ketidakpastian yang menimbulkan akibat yang merugikan atau menimpang dari tujuan yang diharapkan. Selain itu, risiko merupakan suatu keadaan yang dihadapi lembaga atau organisasi, dimana terdapat kemungkinan yang merugikan [7]. Risiko merupakan probabilitas suatu peristiwa yang akan terjadi selama waktu tertentu dan mengakibatkan kerugian [8].

\subsection{Manajemen Risiko}

Manajemen risiko adalah suatu metodolgi yang berfungsi untuk megidentifikasi, pengukuran, pemantauan, dan pengendalian terhadap risiko yang muncul pada kegiatan operasional [14]. Manajemen risiko membantu pengambilan keputusan dengan adanya pertimbangan ketidakpastian dan pengaruhnya dalam pencapaian tujuan [9]. Manajemen risiko merupakan bagian integrasi dari proses manajemen yang dilakukan secara terus-menerus yang digunakan untuk mengurangi kerugian dan meningkatkan peluang [15].

\subsection{Manajemen Risiko Rantai Pasok}

Risiko rantai pasok merupakan probabilitas dan kemungkinan dari kejadian yang tidak diinginkan baik dalam skala mikro ataupun makro yang memberikan pengaruh negatif pada rantai pasok dan menyebabkan kegagalan pada proses operasional, taktis dan strategis [7]. Manajemen risiko rantai pasok (supply chain risk management) merupakan aktivitas kegiatan yang terdiri dari mengidenfitikasi, mengukur, menangani, dan pengendalian risiko pada rantai pasok [16]. Proses manajemen risiko rantai pasok meliputi identifikasi risiko, analisis risiko, evaluasi risiko dan mitigasi risiko [7].

\section{Metodologi}

\subsection{Objek Penelitian}

Objek penelitian yaitu sistem rantai pasok ikan bandeng pada kelompok Tani Tambak Bungkak. Pada sistem rantai pasok tersebut akan dilakukan analisis dari risiko tersebut.

\subsection{Jumlah Responden}

Responden yang digunakan sebanyak 1 responden saja. Dalam penelitian mengenai responden yaitu Ketua Tani Tambak Bungkak di Desa Banyuwangi Kecamatan Manyar Kabupaten Gresik. Responden yang dipilih merupakan orang yang menguasai dan kompeten di bidangnya. Selain itu, responden tersebut dianggap paling memahami keseluruhan dari proses. Hal ini juga sesuai dengan konsep metode yang digunakan dalam penyelesaian yaitu ANP dan FMEA dimana responden yang diambil hanya yang expert atau paham dari bidangnya. 


\subsection{Alat Penelitian}

Alat penelitian yang digunakan meliputi : Ms. Excel, Kuesioner dan software Super decision.

\subsection{Pengumpulan data}

Dalam pengumpulan data dilakukan berdasarkan interview langsung dan juga berdasarkan studi literatur yang ada yang disesuaikan dan didiskusikan dengan objek penelitian. Pada pengumpulan data, melakukan pengumpulan struktur yang terlibat dalam risiko rantai pasok yang akan digunakan dalam kerangkan desain ANP. Adapun hasil pengumpulan data sebagai berikut :

Tabel 1 Struktur yang terlibat dalam risiko rantai pasok

\begin{tabular}{|c|c|}
\hline Kluster & Kriteria \\
\hline Aktor & $\begin{array}{l}\text { - Petani Tambak Ikan } \\
\text { - Pedagang Pengumpul } \\
\text { Ikan } \\
\text { - Industri Pengolahan } \\
\text { Ikan }\end{array}$ \\
\hline Masalah & $\begin{array}{l}\text { - Fluktuasi Harga } \\
\text { - Fluktuasi Pendapatan } \\
\text { - Kestabilan Pemasokan } \\
\text { Ikan } \\
\text { - Kualitas Ikan } \\
\text { - Pencemaran Limbah }\end{array}$ \\
\hline Faktor Risiko & $\begin{array}{l}\text { - Produksi } \\
\text { - Lingkungan } \\
\text { - Harga } \\
\text { - Kualitas } \\
\text { - Pasokan }\end{array}$ \\
\hline
\end{tabular}

Selain pengumpulan data untuk pembuatan kerangka ANP risiko rantai pasok, maka dilakukan pengumpulan data indikator dari faktor risiko yang akan digunakan dalam pengolahan dengan metode FMEA, adapun dijelaskan dalam tabel berikut :

Tabel 2 Indikator dari faktor risiko

\begin{tabular}{lll}
\hline No & \multicolumn{1}{c}{ Faktor } & \multicolumn{1}{c}{ Indikator } \\
\hline & & Luas lahan budidaya ikan \\
1 & Produksi & Proses pengairan tidak efisien \\
& & Pertumbuhan ikan melambat \\
& & Cuaca \\
& & Pencemaran limbah \\
& Lingkungan & Kondisi sosial \\
\end{tabular}


Tabel 2. Indikator dari faktor risiko

\begin{tabular}{lll}
\hline No & \multicolumn{1}{c}{ Faktor } & \multicolumn{1}{c}{ Indikator } \\
\hline & & Terdapat hama dan penyakit \\
& & Tempat penyimpanan tidak ada \\
& & Pemahaman budidaya ikan masih \\
& Kualitas & tradisional \\
& & Kesepakatan harga \\
& & Fluktuasi harga \\
$4 \quad$ harga & Kestabilan pasokan ikan \\
& & Ketersediaan bibit ikan \\
&
\end{tabular}

\subsection{Kerangka Desain ANP Risiko Rantai Pasok Ikan Bandeng}

Berikut merupakan kerangka desain Analytic Network Process untuk risiko rantai pasok ikan bandeng :
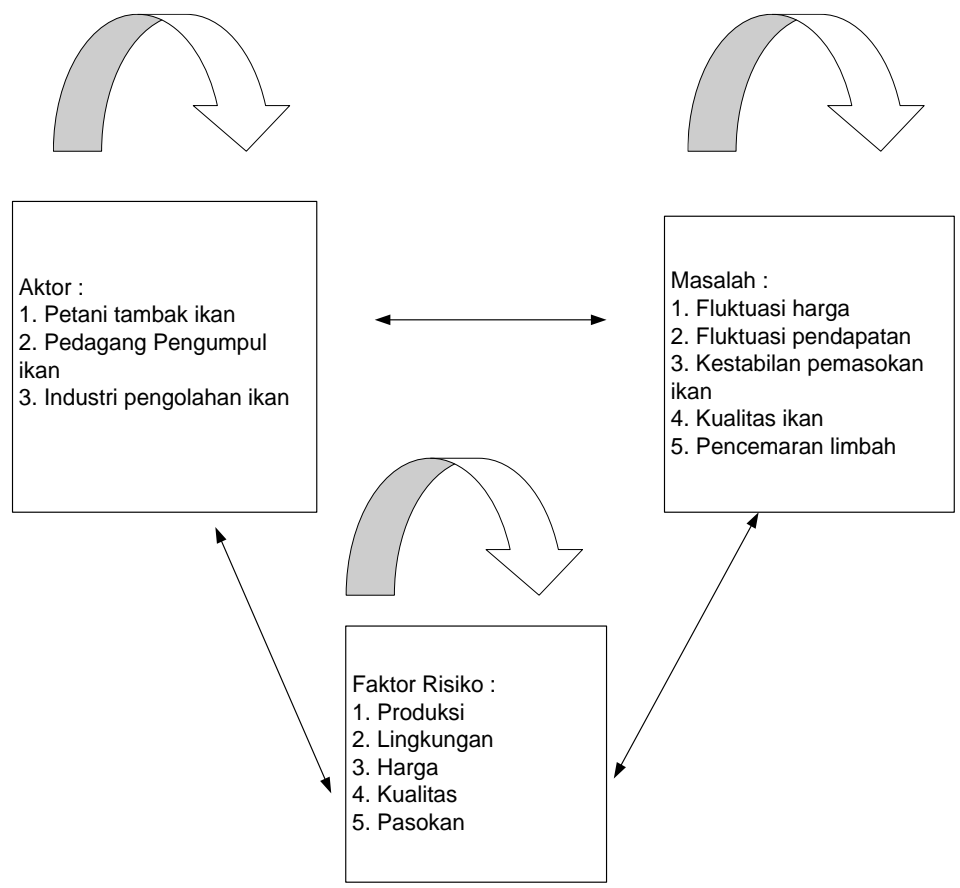

Gambar 2 Kerangka ANP risiko rantai pasok ikan bandeng

\subsection{Tahapan Penyelesaian}

Adapun tahapan penyelesaian dari penelitian sebagai berikut :

\subsubsection{Analytic Network Process (ANP).}

Pada tahapan analytic network process sebagai berikut [10] : 
Tahap 1 : pembuatan konstruksi model dan strukturisasi masalah. Konstruksi model dibuat berdasarkan masalah yang ada, sehingga perlu dilakukan suatu deskripsi masalah secara jelas, kemudian membentuknya ke dalam jaringan.

Tahap 2 : Melakukan penilaian pembobotan pada perbandingan berpasangan. Pedoman pemberian nilai menggunakan skala kuantitatif antara 1 sampai 9. Pedoman pemberian nilai digunakan untuk memberikan nilai perbandingan tingkat kepentingan suatu elemen terhadap elemen lainnya.

Tabel 3 Pedoman Pemberian nilai menurut saaty

\begin{tabular}{|c|c|c|}
\hline Tingkat kepentingan & Definisi & Keterangan \\
\hline 1 & Sama penting & $\begin{array}{l}\text { Kedua kriteria memiliki } \\
\text { pengaruh yang sama }\end{array}$ \\
\hline 3 & Sedikit lebih penting & $\begin{array}{l}\text { Penilaian sedikit lebih } \\
\text { memihak pada salah satu } \\
\text { kriteria disbanding } \\
\text { pasangannya }\end{array}$ \\
\hline 5 & Lebih Penting & $\begin{array}{l}\text { Penilaian sangat } \\
\text { memihak pada salah satu } \\
\text { kriteria disbanding } \\
\text { pasangannya }\end{array}$ \\
\hline 7 & Sangat Penting & $\begin{array}{l}\text { Salah satu kriteria sangat } \\
\text { berpengaruh dan } \\
\text { dominasinya tampak } \\
\text { secara nyata }\end{array}$ \\
\hline 9 & Mutlak sangat penting & $\begin{array}{l}\text { Salah satu kriteria } \\
\text { terbukti mutlak lebih } \\
\text { disukai dibandingkan } \\
\text { dengan pasangannya }\end{array}$ \\
\hline $2,4,6,8$ & Nilai Tengah & $\begin{array}{l}\text { Jika terdapat keraguan } \\
\text { diantara kedua penilaian } \\
\text { yang berdekatan }\end{array}$ \\
\hline
\end{tabular}

Tahap 3 : Membuat matriks pairwise comparison. Pada tahap ini melakukan perbandingan semua alternatif yang saling berkaitan pada masing elemen-elemen dalam komponen. Contoh matriks parwise comparison yaitu :

\begin{tabular}{cccccc}
\hline$C$ & $A_{1}$ & $A_{2}$ & $A_{3}$ & $\cdots$ & $A_{n}$ \\
\hline$A_{1}$ & $a_{11}$ & $a_{12}$ & $a_{13}$ & $\cdots$ & $a_{1 n}$ \\
$A_{2}$ & $a_{21}$ & $a_{22}$ & $a_{23}$ & $\cdots$ & $a_{2 n}$ \\
$A_{3}$ & $a_{31}$ & $a_{32}$ & $a_{33}$ & $\cdots$ & $a_{3 n}$ \\
$\cdots$ & $\cdots$ & $\cdots$ & $\cdots$ & $\cdots$ & $\cdots$ \\
$A_{n}$ & $a_{n 1}$ & $a_{n 2}$ & $a_{n 3}$ & $\cdots$ & $a_{n n}$ \\
\hline
\end{tabular}

\section{Gambar 3 matriks parwise comparison}

Tahap 4 : perhitungan bobot elemen (nilai eigenvector). Setelah melakukan penilaian matriks perbandingan berpasangan, maka tahapan selanjutnya menentukan nilai eigen dari matriks tersebut. Perhitungan eigenvector dengan cara menjumlahkan nilai setiap kolom dari matriks 
kemudian membagi setiap nilai sel kolom dengan total kolom dan menjumlahkan nilai-nilai dari setiap baris dan dibagi $\mathrm{n}$. Nilai eigenvector dihitung dengan rumus sebagai berikut [10]:

$$
X_{i}=\frac{\sum_{j=1}^{n}\left(\frac{W_{i j}}{\sum W_{j}}\right)}{n}
$$

\section{Keterangan :}

$\mathrm{Xi} \quad$ : eigen vector baris $\mathrm{i}$

$\mathrm{i}, \mathrm{j} \quad$ : baris, kolom

$\mathrm{W}_{\mathrm{ij}}$ : nilai satu baris $\mathrm{i}(\mathrm{i}=1,2, \ldots \mathrm{n})$

$\Sigma \mathrm{W}_{\mathrm{j}}$ : jumlah total kolom $\mathrm{j}(\mathrm{j}=1,2, \ldots \mathrm{n})$

$\mathrm{n} \quad$ : ukuran ordo matriks

Tahap 5 : perhitungan nilai rasio konsistensi. Rasio konsistensi yaitu rasio yang menyatakan apakah penilaian yang diberikan oleh para expertise sudah konsisten atau belum. Tahapan awal mencari nilai Kmax dengan rumus [10]:

$$
\lambda \max =\sum_{i, j}^{n}\left(\sum W_{j} x X_{i}\right)
$$

Keterangan :

$\mathrm{W}_{\mathrm{j}} \quad$ : jumlah total kolom $\mathrm{j}(\mathrm{j}=1,2, \ldots \mathrm{n})$

$\mathrm{X}_{\mathrm{i}} \quad$ : eigenvector (bobot) baris i

Tahap selanjutnya melakukan perhitungan nilai indesk konsistensi dari suatu matriks perbandingan dengan rumus [10]:

$\mathrm{CI}=\frac{\lambda_{\max }-n}{n-1}$

Tahap selanjutnya perhitungan rasio konsistensi. Nilai tersebut diperoleh dengan membandingkan nilai indeks konsistensi dengan nilai dari bilangan indeks konsistensi acak (Random consistency index/RI). Rumus sebagai berikut [10]:

$$
\mathrm{CR}=\mathrm{CI} / \mathrm{RI}
$$

Keterangan :

$\lambda \max \quad$ : Nilai eigen terbesar dari matriks perbandingan berpasangan $\mathrm{n} \times \mathrm{n}$

$\mathrm{n} \quad$ : Jumlah item yang diperbandingkan (ukuran matriks)

CI $\quad$ : Indeks konsistensi

RI : Random Index

Tahap 6 : Membuat supermatrix. Pada supermatrix terdiri dari sub-sub matrix yang disusun dari suatu set hubungan antara dua level yang terdapat dalam model. 
Tahap 7 : Pemilihan alternatif terbaik. Pada tahap ini, melakukan perhitungan terhadap nilai elemen-elemen tersebut sesuai dengan model ANP yang dibuat. Alternatif dengan prioritas global tertinggi adalah alternatif yang terbaik.

\subsubsection{FMEA (Failure Mode and Effect Analysis)}

Pada tahapan FMEA (failure mode and effect analysis) melakukan perhitungan risk priority number (RPN). Risk priority number (RPN) merupakan nilai dari masing-masing penyebab kegagalan yang diperoleh dari hasil perkalian keparahan (severity), kejadian (occurance), dan deteksi (detection). Ukuran penilaian masing masing komponen yaitu nilai severity $=1-10$, semakin besar nilai severity, maka semakin tinggi tingkat keparahan, nilai occurance $=1-10$, semakin besar nilai occurance, maka semakin tinggi peluang terjadinya kegagalan dalam proses, nilai detection $=1-10$, semakin besar nilai detection, maka semakin rendah tingkat keandalan mendeteksi kegagalan dalam proses [17]. Nilai RPN tertinggi akan menjadi prioritas perbaikan. Rumus RPN sebagai berikut :

$$
\mathrm{RPN}=\mathrm{S} \times \mathrm{O} \times \mathrm{D}
$$

Keterangan :

$$
\begin{array}{ll}
\mathrm{S} & =\text { severity } \\
\mathrm{O} & =\text { occurance } \\
\mathrm{D} & =\text { detection } \\
\mathrm{RPN} & =\text { risk priority number }
\end{array}
$$

\subsubsection{Integrasi ANP (Analytic Network Process) dengan FMEA (Failure Mode and Effect Analysis)}

Integrasi yang dilakukan pada meode ANP (analytic network process) dan FMEA (failure mode and effect analysis) yaitu hasil penyelesaian dari metode ANP berupa nilai bobot (weighted) dikalikan dengan nilai RPN FMEA, dimana hasil tersebut akan dikenal dengan nama WRPN (wighted risk priority number). Hasil WRPN akan dijadikan untuk evaluasi dan pengendalian risiko. Rumus WRPN sebagai berikut [11] :

$\mathrm{WRPN}_{\mathrm{n}}=\mathrm{RPN}_{\mathrm{n}} \mathrm{x} \mathrm{f}\left(\mathrm{W}_{\mathrm{i}}\right)$

Keterangan :

$\mathrm{f}\left(\mathrm{W}_{\mathrm{i}}\right) \quad=$ nilai bobot

$\mathrm{RPN}=$ risk priority number

Berikut merupakan kategori risiko berdasarkan nilai WRPN : 
Tabel 4 kategori risiko berdasarkan nilai WRPN

\begin{tabular}{llc}
\hline Nilai output & Kategori risiko & Pengendalian risiko \\
\hline $1-50$ & Sangat rendah & Menerima \\
$50-100$ & Rendah & Menerima \\
$100-150$ & Menengah & Menghindari \\
$150-200$ & Tinggi & Mitigasi \\
$200-250$ & Sangat tinggi & Mitigasi
\end{tabular}

\subsubsection{Flowchart Penelitian}

Berikut merupakan alur (flowchart) dari penelitian : 


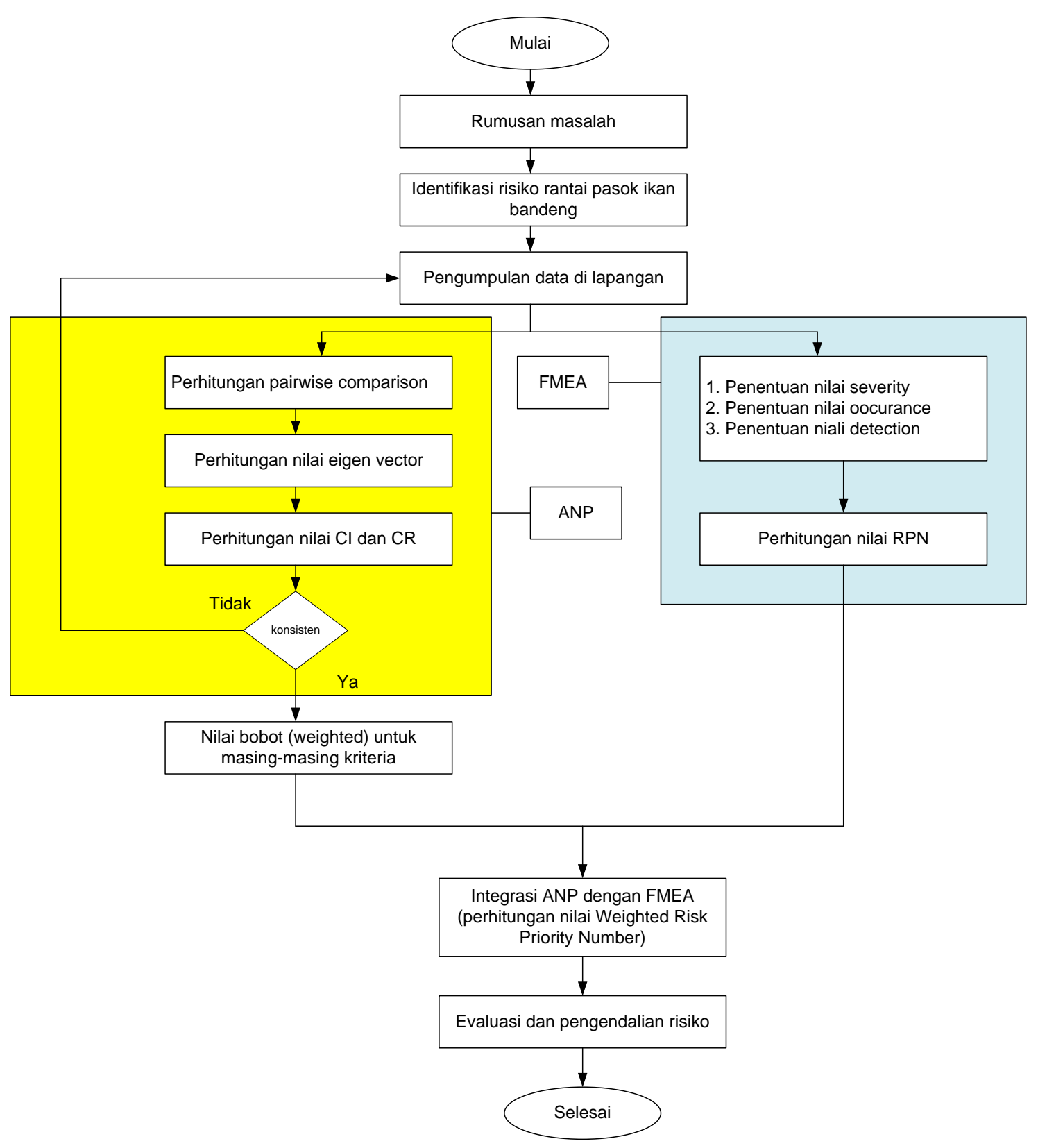

Gambar 4 Flowchart Penelitian

\section{Hasil dan Pembahasan}

\subsection{Rantai pasok ikan bandeng}

Berikut merupakan rantai pasok ikan bandeng pada penelitian :

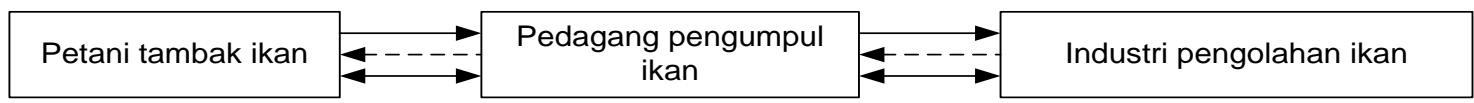

Gambar 5 Rantai pasok ikan bandeng

Keterangan :

$\longrightarrow \quad$ : aliran pergerakan bahan baku : ikan bandeng

: aliran pergerakan uang

$\longleftrightarrow$ : aliran pergerakan informasi 
Dari gambar 5, dapat dijelaskan bahwa rantai pasok ikan bandeng dimulai dari pihak hulu yaitu petani tambak ikan bandeng pada kelompok tani tambak bungkak, garis anak panah satu arah menuju ke pihak hilir yaitu pedanga pengumpulkan ikan. Pada tahap ini terjadi pergerakan aliran bahan baku ikan bandeng ke pihak pedagang pengumpulkan pada garis anak panah putus-putus menggambarkan aliran keuangan sedangkan garis dengan anak panah dua arah menandkan alirang informasi kedua belah pihak.

\subsection{Hasil Pengolahan dengan Metode Analytic Network Process}

Berdasarkan hasil pengolahan dari metode analytic network process, maka diperoleh hasil sebagai berikut:

\subsubsection{Piroritas Kluster Aktor Rantai Pasok Ikan Bandeng}

Berikut merupakan hasil prioritas dari kluster aktor berdasarkan pengolahan metode analytic network process dengan software superdecision :

Tabel 5 Prioritas kluster aktor

\begin{tabular}{clc}
\hline Kluster & \multicolumn{1}{c}{ Kriteria } & Normalized by cluster \\
\hline \multirow{3}{*}{ Aktor } & Petani tambak ikan bandeng & 0,518 \\
& $\begin{array}{l}\text { Pedagang pengumpul ikan } \\
\text { bandeng }\end{array}$ & 0,252 \\
& $\begin{array}{l}\text { Industri pengolahan ikan } \\
\text { bandeng }\end{array}$ & 0,232 \\
\hline
\end{tabular}

Dari hasil pengolahan diatas, dapat dijelaskan bahwan proritas kluster aktor pada rantai pasok ikan bandeng yaitu petani tambak ikan dengan nilai normalized by cluster sebesar 0,518 . Hasil ini sesuai dengan penelitian oleh [11] tentang tentang risiko rantai pasok kakao di Indonesia dengan metode analytic network process dan failure mode and effect analysis yang terintegrasi. Petani tambak ikan menjadi aktor yang paling tinggi diaintara aktor lain karena sebagai sentral yang paling penting dalam proses ketersediaan bahan baku yaitu ikan bandeng dan juga proses distribusi ikan bandeng agar proses rantai pasok berjalan efektif.

\subsubsection{Piroritas Kluster Masalah Rantai Pasok Ikan Bandeng}

Berikut merupakan hasil prioritas dari kluster masalah berdasarkan pengolahan metode analytic network process dengan software superdecision : 
Tabel 6 Prioritas kluster masalah

\begin{tabular}{lll}
\hline Kluster & \multicolumn{1}{c}{ Kriteria } & Normalized by cluster \\
\hline & Fluktuasi harga & 0,137 \\
& Fluktuasi pendapatan & 0,239 \\
Masalah & Kestabilan pemasokan ikan & 0,231 \\
& Kualitas ikan & 0,177 \\
& Pencemaran limbah & 0,214 \\
\hline
\end{tabular}

Dari hasil pengolahan diatas, dapat dijelaskan bahwan proritas kluster masalah pada rantai pasok ikan bandeng yaitu fluktuasi pendapatan dengan nilai normalized by cluster sebesar 0,239 . Hal ini dapat diambil kesimpulan bahwa dalam proses manejemen risiko rantai pasok ikan bandeng memiliki masalah utama dengan adanya naik turunnya pendapatan akan mempengaruhi dalam proses produksi budidaya tambak ikan bandeng, dan juga proses pasokan ikan.

\subsubsection{Piroritas Kluster Faktor Risiko Rantai Pasok Ikan Bandeng}

Berikut merupakan hasil prioritas dari kluster faktor risiko berdasarkan pengolahan metode analytic network process dengan software superdecision :

Tabel 7 Prioritas kluster faktor risiko

\begin{tabular}{llc}
\hline Kluster & Kriteria & Normalized by cluster \\
\hline & Produksi & 0,234 \\
& Lingkungan & 0,132 \\
$\begin{array}{c}\text { Faktor } \\
\text { risiko }\end{array}$ & Harga & 0,244 \\
& Kualitas & 0,244 \\
& Pasokan & 0,142 \\
\hline
\end{tabular}

Dari hasil pengolahan diatas, dapat dijelaskan bahwan proritas kluster faktor risiko pada rantai pasok ikan bandeng yaitu harga dan kualitas dengan nilai normalized by cluster sama sebesar 0,244 . Hal ini berbeda dengan penelitian sebelumnya, dimana risiko tertinggi terdapat pada risiko produksi. Faktor risiko harga dan kualitas menjadi utama dalam manajemen risiko rantai pasok ikan bandeng, karena saling keterkaitan, dimana semakin bagus tingkat kualitas ikan maka semakin tinggi nilai harganya. 


\subsection{Hasil Pengolahan dengan Metode FMEA (Failure Mode and Effect Analysis)}

Metode FMEA digunakan untuk menentukan prioritas dari faktor risiko berdsasarkan nilai risk priority number (RPN). Berdasarkan hasil pengolahan dari metode FMEA (failure mode and effect analysis), maka diperoleh hasil sebagai berikut:

Tabel 8 Hasil pengolahan risiko dengan FMEA

\begin{tabular}{|c|c|c|c|c|c|c|c|}
\hline No & Faktor & Indikator & Severity & Occurance & Detection & RPN & $\begin{array}{l}\text { Total RPN } \\
\text { Kumulatif }\end{array}$ \\
\hline \multirow{3}{*}{1} & \multirow{3}{*}{ Produksi } & $\begin{array}{l}\text { Luas lahan } \\
\text { budidaya ikan }\end{array}$ & 4 & 9 & 5 & 180 & \multirow{3}{*}{796} \\
\hline & & $\begin{array}{l}\text { Proses } \\
\text { pengairan } \\
\text { tidak efisien }\end{array}$ & 7 & 4 & 6 & 168 & \\
\hline & & $\begin{array}{l}\text { Pertumbuhan } \\
\text { ikan } \\
\text { melambat }\end{array}$ & 8 & 7 & 8 & 448 & \\
\hline \multirow{3}{*}{2} & \multirow{3}{*}{ Lingkungan } & Cuaca & 9 & 1 & 10 & 90 & \multirow{3}{*}{544} \\
\hline & & $\begin{array}{l}\text { Pencemaran } \\
\text { limbah }\end{array}$ & 8 & 7 & 8 & 448 & \\
\hline & & $\begin{array}{l}\text { Kondisi sosial } \\
\text { Terdapat }\end{array}$ & 3 & 2 & 1 & 6 & \\
\hline \multirow{3}{*}{3} & \multirow{3}{*}{ Kualitas } & $\begin{array}{l}\text { hama dan } \\
\text { penyakit }\end{array}$ & 9 & 6 & 8 & 432 & \multirow{3}{*}{492} \\
\hline & & $\begin{array}{l}\text { Tempat } \\
\text { penyimpanan } \\
\text { tidak ada }\end{array}$ & 4 & 2 & 3 & 24 & \\
\hline & & $\begin{array}{l}\text { Pemahaman } \\
\text { budidaya ikan } \\
\text { masih } \\
\text { tradisional }\end{array}$ & 3 & 6 & 2 & 36 & \\
\hline \multirow{2}{*}{4} & \multirow{2}{*}{ Harga } & $\begin{array}{l}\text { Kesepakatan } \\
\text { harga }\end{array}$ & 9 & 8 & 7 & 504 & \multirow{2}{*}{629} \\
\hline & & $\begin{array}{l}\text { Fluktuasi } \\
\text { harga }\end{array}$ & 5 & 5 & 5 & 125 & \\
\hline \multirow{2}{*}{5} & \multirow{2}{*}{ Pasokan } & $\begin{array}{l}\text { Kestabilan } \\
\text { pasokan ikan }\end{array}$ & 5 & 4 & 5 & 100 & \multirow{2}{*}{220} \\
\hline & & $\begin{array}{l}\text { Ketersediaan } \\
\text { bibit ikan }\end{array}$ & 6 & 4 & 5 & 120 & \\
\hline
\end{tabular}

Dari hasil pengolahan diatas, dapat dijelaskan bahwa prioritas untuk perbaikan pada faktor risiko yaitu pada produksi dengan nilai RPN kumulatif sebesar 796. Risiko pada produksi meliputi tekonologi panen manual dengan nilai RPN sebesar 180, proses pengairan tidak efisien dengan nilai RPN sebesar 168, pertumbuhan ikan melambat dengan nilai RPN sebesar 448. Hasil ini sesuai dengan penelitian sebelumnya oleh [11] tentang risiko rantai pasok kakao di Indonesia dengan metode analytic network process dan failure mode and effect analysis yang terintegrasi dan [6] tentang manajemen risiko rantai pasok tebu (studi kasus PTPN X), dimana hasil prioritas risiko terdapat pada faktor risiko produksi. 


\subsection{Hasil Penilaian Faktor Risiko Berdasarkan Integrasi antara ANP (Analytic Network Process) dengan FMEA (Failure Mode and Effect Analysis)}

Berikut merupakan hasil pengolahan penentuan prioritas perbaikan risiko berdasarkan integrasi dari metode analytic network Process dengan FMEA (failure mode and effect analysis). Yang akan diperoleh nilai weighted risk priority number (WRPN) dari masing-masing risiko :

Tabel 9 Hasil perhitungan nilai WRPN

\begin{tabular}{llcccc}
\hline Kluster & Kriteria & $\begin{array}{c}\text { Nilai bobot } \\
(\text { Weighted })\end{array}$ & RPN & WRPN & Peringkat \\
\hline & Produksi & 0,234 & 796 & 186,26 & 1 \\
& Lingkungan & 0,132 & 544 & 71,80 & 4 \\
$\begin{array}{c}\text { Faktor } \\
\text { risiko }\end{array}$ & Harga & 0,244 & 492 & 120,05 & 3 \\
& Kualitas & 0,244 & 629 & 153,48 & 2 \\
& Pasokan & 0,142 & 220 & 31,24 & 5 \\
\hline
\end{tabular}

Dari hasil pengolahan diatas, dijelaskan bahwa prioritas perbaikan atau pengendaian risiko yaitu pada produksi dengan nilai WRPN sebesar 186,26. Dari hasil perhitungan terdapat beberapa perbedaan, dimana pada hasil pengolahan dengan ANP (analytic network process) diperoleh faktor risiko tertinggi terdapat pada harga dan kualitas, namun pada pengolahan FMEA (failure mode and effect analysis) faktor risiko tertinggi terdapat pada produksi. Namun, setelah dilakukan integrasi antara hasil ANP dengan FMEA yang diperoleh dengan WRPN sebagai keputusan hasil akhir, maka faktor risiko tertinggi terdapat pada produksi. Hal ini sesuai dengan penelitian oleh diperoleh [11] tentang risiko rantai pasok kakao di Indonesia dengan metode analytic network process dan failure mode and effect analysis yang terintegrasi, dimana faktor risiko tertinggi terdapat pada produksi.

\subsection{Evaluasi dan Pengendalian Risiko Rantai Pasok Ikan Bandeng}

Berikut merupakan evaluasi risiko dan pengendalian risiko yang digunakan untuk mengetahui tingkat risiko berdasarkan standar yang digunakan.

Tabel 10 Evaluasi risiko dan pengendalian risiko

\begin{tabular}{lllll}
\hline Kluster & Kriteria & WRPN & $\begin{array}{c}\text { Kategori } \\
\text { Risiko }\end{array}$ & $\begin{array}{c}\text { Pengendalian } \\
\text { Risiko }\end{array}$ \\
\hline & Produksi & 186,26 & Tinggi & Mitigasi \\
& Lingkungan & 71,80 & Rendah & Menerima \\
$\begin{array}{c}\text { Faktor } \\
\text { risiko }\end{array}$ & Harga & 120,05 & Menengah & Menghindari \\
& Kualitas & 153,48 & Tinggi & Mitigasi \\
\hline
\end{tabular}


Tabel 11 Evaluasi risiko dan pengendalian risiko

\begin{tabular}{ccccc}
\hline Kluster & Kriteria & WRPN & $\begin{array}{c}\text { Kategori } \\
\text { Risiko }\end{array}$ & $\begin{array}{c}\text { Pengendalian } \\
\text { Risiko }\end{array}$ \\
\hline & Pasokan & 31,24 & Sangat rendah & Menerima \\
\hline
\end{tabular}

Berdasarkan hasil tersebut, maka pengendalian risiko dilakukan pada yang prioritas berdasarkan nilai tertinggi WRPN yaitu produksi secara mitigasi. Pada risiko luas lahan yaitu luas lahan yang ada pada budi daya ikan bandeng bervariasi dan berpengaruh pada pertumbuhan ikan, hal ini berdampak pada proses produksi. Pengendalian risiko yang dapat dilakukan petani tambak ikan pada kelompok tani tambak bungkak yaitu pemberian edukasi tentang luas lahan yang baik untuk budi daya ikan yaitu sebesar 1 hektar, karena dapat merangsang pertumbuhan ikan bandeng. Selain itu, juga dapat koordinasi pemberian pinjaman keuangan untuk memperluas lahan budi daya ikan.

Risiko proses pengairan tidak efisien karena mengandalkan pasang air laut. Pengendalian risiko yang dilakukan dengan pembuatan waduk penampungan air, sehingga mempermudah dalam proses pengairan sesuai kebutuhan petani.

Risiko pertumbuhan ikan melambat disebabkan kurangnya nutrisi pada ikan, pengendalian risiko dapat dilakukan dengan memberikan nutrisi tambahan seperti pelet dan juga mengatur kondisi air.

\subsection{Implikasi Manajerial pada Manajemen Risiko Rantai Pasok Ikan Bandeng.}

Implikasi manajerial pada manajamen risiko rantai pasok ikan bandeng merupakan upaya pengendalian risiko dengan melibatkan seluruh elemen yang ada dalam rantai pasok ikan bandeng tersebut. Hal ini berguna untuk peningkatan daya saing dan produktivitas kinerja dari para petani budi daya ikan bandeng khususnya kelompok tani Tambak Bungkak di Kabupaten Gresik. Adapun implikasi manajerial sebagai berikut :

Tabel 11 Implikasi manajerial risiko rantai pasok ikan bandeng

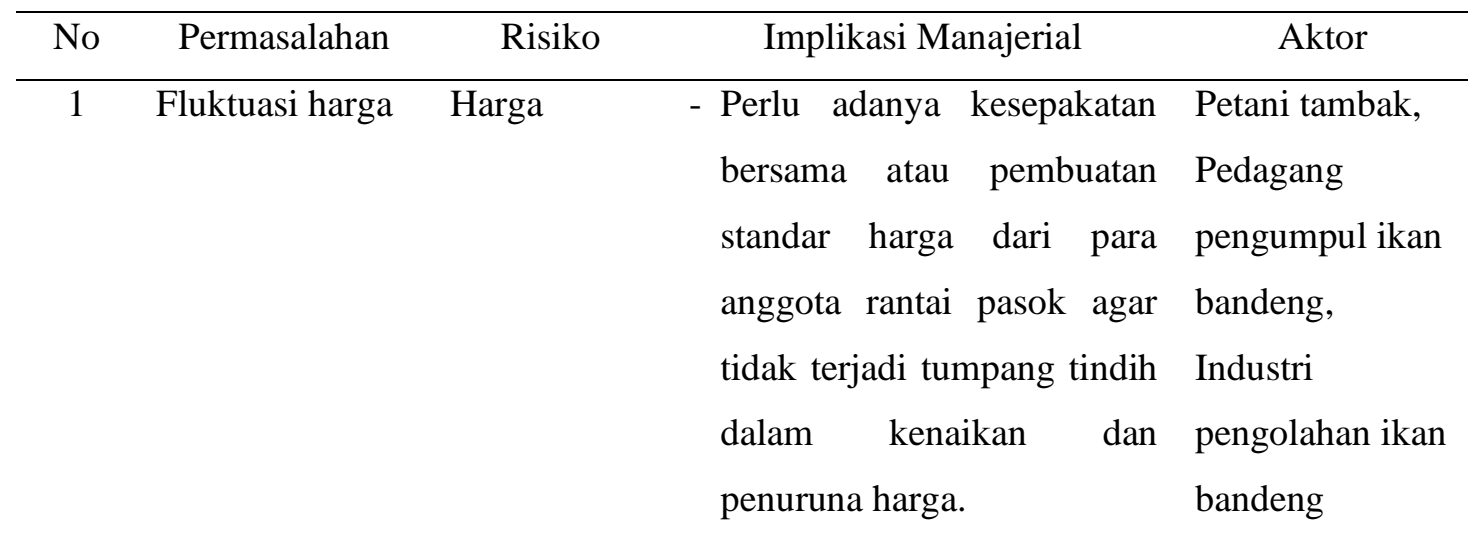


Tabel 12 Implikasi manajerial risiko rantai pasok ikan bandeng

\begin{tabular}{|c|c|c|c|c|}
\hline No & Permasalahan & Risiko & Implikasi Manajerial & Aktor \\
\hline 2 & $\begin{array}{l}\text { Fluktuasi } \\
\text { pendapatan }\end{array}$ & $\begin{array}{l}\text { Harga, } \\
\text { Kualitas }\end{array}$ & $\begin{array}{l}\text { - Pembuatan bak } \\
\text { penampungan ikan segar } \\
\text { dengan kapasitas untuk } \\
\text { menampung hasil panen } \\
\text { ikan agar ikan selalu segar } \\
\text { dan tidak layu serta terjaga } \\
\text { kualitasnya. }\end{array}$ & $\begin{array}{l}\text { Petani tambak, } \\
\text { Pedagang } \\
\text { pengumpul } \\
\text { ikan bandeng, } \\
\text { Industri } \\
\text { pengolahan } \\
\text { ikan bandeng }\end{array}$ \\
\hline 3 & $\begin{array}{l}\text { Kestabilan } \\
\text { pemasokan } \\
\text { ikan }\end{array}$ & Produksi & $\begin{array}{l}\text { - Perlunya perencanaan } \\
\text { yang baik mengenai } \\
\text { proses budi daya ikan } \\
\text { bandeng mulai dari masa } \\
\text { pembibitan hingga masa } \\
\text { panen, sehingga proses } \\
\text { permintaan dan men- } \\
\text { supply dapat terjadwal dan } \\
\text { terdistribusi dengan baik. }\end{array}$ & $\begin{array}{l}\text { Petani tambak, } \\
\text { Pedagang } \\
\text { pengumpul } \\
\text { ikan bandeng }\end{array}$ \\
\hline 4 & Kualitas ikan & $\begin{array}{l}\text { Kualitas, } \\
\text { lingkungan }\end{array}$ & $\begin{array}{l}\text { - Perlu adanya workshop } \\
\text { atau sosialisasi mengenai } \\
\text { standar kualitas ikan } \\
\text { bandeng yang baik }\end{array}$ & $\begin{array}{l}\text { Petani tambak, } \\
\text { Pedagang } \\
\text { pengumpul } \\
\text { ikan bandeng, } \\
\text { Industri } \\
\text { pengolahan } \\
\text { ikan bandeng }\end{array}$ \\
\hline 5 & $\begin{array}{l}\text { Pencemaran } \\
\text { limbah }\end{array}$ & Lingkungan & $\begin{array}{l}\text { Pembuatan filter pada } \\
\text { pintu air ditambak, } \\
\text { pembuatan filter } \\
\text { digunakan menyarig } \\
\text { kotoran agar tidak masuk } \\
\text { kedalam tambak }\end{array}$ & Petani tambak \\
\hline
\end{tabular}




\section{Kesimpulan dan Penelitian Selanjutnya}

Kesimpulan yang didpatkan dari penelitian yaitu rantai pasok ikan bandeng terdiri dari petani tambak ikan, pedagang pengumpul ikan, dan industri pengolahan ikan. Dari ketiga rantai pasok tersebut terjadi aliran pergerakan bahan baku ikan bandeng, uang dan informasi. Dari hasil pengolahan dengan metode analytic network process diperoleh prioritas tertinggi ada di kluster aktor yaitu petani tambak ikan bandeng dengan nilai bobot 0,518. Dari hasil FMEA diperoleh nilai RPN tertinggi terdapat pada risiko produksi dengan nilai RPN kumulatif sebesar 796.

Dari hasil integrasi antara metode ANP dengan FMEA, maka risiko yang menjadi priorititas yaitu pada produksi dengan nilai WRPN sebesar 186,26. Pengendalian risiko yang dilakukan pada kriteria risiko produksi yaitu luas lahan budi daya ikan adalah edukasi tentang luas lahan yang baik untuk budi daya ikan yaitu sebesar 1 hektar, karena dapat merangsang pertumbuhan ikan bandeng. Selain itu, juga dapat koordinasi pemberian pinjaman keuangan untuk memperluas lahan budi daya ikan. Pengendalian risiko yang dilakukan pada kriteria risiko produksi yaitu proses pengairan tidak efisien adalah pembuatan waduk penampungan air, sehingga mempermudah dalam proses pengairan sesuai kebutuhan petani. Pengendalian risiko yang dilakukan pada kriteria risiko produksi yaitu pertumbuhan ikan melambat adalah memberikan nutrisi tambahan seperti pelet dan juga mengatur kondisi air.

Penelitian ini melakukan identifikasi risiko, analisis risiko serta evaluasi dan pengendalian risiko pada rantai pasok ikan bandeng khususnya kelompok tani ikan bandeng yang ada di kabupaten gresik. Budi daya ikan bandengan merupakan bisnis yang banyak dilakukan oleh sebagin besar warga gresik. Penelitian tersebut dilakukan karena sistem rantai pasok sangatlah penting dalam mengatur proses jalannya distribusi pasokan ikan, karena gresik sebagai salah satu pusat produksi ikan bandeng di jawa timur. Namun adanya risiko yang terjadi membuat proses tersebut terhambat dam proses pasokan tidak berjalan dengan baik. Hal ini akan berdampak pada berbagai hal seperti harga, kualitas, produksi dan lainnya. Penelitian selanjutnya dapat melakukan proses pengaturan penjadwalan yang optimal dalam keseimbangan jaringan rantai pasok ikan bandeng.

\section{References.}

[1] Kementerian Kelautan dan Perikanan, "Refleksi Outlook," in Refleksi Outlook Kementerian Kelautan dan Perikanan, 2019, p. 67.

[2] E. N. Dewi, L. Purnamayati, and R. A. Kurniasih, "KARAKTERISTIK MUTU IKAN BANDENG (Chanos chanos Forsk.) DENGAN BERBAGAI PENGOLAHAN," J. Pengolah. Has. Perikan. Indones., vol. 22, no. 1, p. 41, 2019.

[3] W. Boy, Zefriyanni, and W. Purba, "Risiko Rantai Pasok Konstruksi Proyek Konstruksi Gedung Pusat Olahraga Pasca Bencana Gempa Bumi Indonesia," Civ. Eng. Colab., vol. 1, no. 1, pp. 92-97, 2000.

[4] E. L. Farhana, D. N. Senjawati, and H. H. Utami, "ANALISIS DAN MITIGASI RISIKO RANTAI PASOK KAKAO DI GRIYA COKELAT NGLANGGERAN GUNUNGKIDUL YOGYAKARTA,” Din. Sos. Ekon., vol. 20, no. 1, pp. 55-64, 2019. 
[5] H. T. Irawan, I. Pamungkas, and Muzakir, "Analisis risiko rantai pasok komoditas cengkeh di kecamatan salang kabupaten simeulue,” Optimalisasi, vol. 5, no. 2, pp. 72-81, 2019.

[6] M. I. Seldon and R. Wibowo, "Manajemen Risiko Rantai Pasok Tebu ( Studi Kasus di PTPN X ) The Supply Chain Risk Management of Sugarcane ( Case Study in PTPN X )," Pangan, vol. 28, no. 3, pp. 203-212, 2020.

[7] M. Ulfah, "Identifikasi Dan Pengelolaan Risiko Rantai Pasok Sentra Produksi Kerajinan Gerabah Desa Bumijaya Dengan Metode House Of Risk," Ind. Serv., vol. 5, no. 2, pp. 188-193, 2020.

[8] S. Melly, R. A. Hadiguna, S. Santosa, and N. Nofialdi, "Manajemen Risiko Rantai Pasok Agroindustri Gula Merah Tebu di Kabupaten Agam, Provinsi Sumatera Barat," Ind. J. Teknol. dan Manaj. Agroindustri, vol. 8, no. 2, pp. 133-144, 2019.

[9] H. K. Hasibuan, A. A. Utami, and K. Umam, "Implementasi Manajemen Risiko Untuk Kredit Macet Konsumtif Di Bank Mandiri Kantor Cabang Jakarta Mampang Prapatan," Relasi J. Ekon., vol. 15, no. 2, pp. 277-292, 2019.

[10] W. A. Syafei, K. Kusnadi, and B. Surarso, "Implementasi Metode Analytic Network Process Untuk Penentuan Prioritas Penanganan Jalan Berdasarkan Tingkat Pelayanan Jalan,” J. Sist. Inf. Bisnis, vol. 6, no. 2, p. 105, 2016.

[11] H. Aini, M. Syamsun, and A. Setiawan, "Risiko Rantai Pasok Kakao Di Indonesia Dengan Metode Analytic Network Process Dan Failure Mode Effect Analysis Terintegrasi," J. Manaj. Agribisnis, vol. 11, no. 3, pp. 209-219, 2015.

[12] R. Jaya et al., "Analisis Dan Mitigasi Risiko Rantai Pasok Minyak Pala Kabupaten Aceh Selatan Menggunakan Fmeca,” J. Teknol. Ind. Pertan., vol. 29, no. 1, pp. 79-87, 2019.

[13] F. M. Hasan, M. Afifuddin, and A. Abdullah, "Hubungan Dan Pengaruh Faktor-Faktor Risiko Rantai Pasok Material Terhadap Kinerja Proyek Pembangunan Gedung Di Kabupaten Pidie Jaya Dan Bireuen,” J. Arsip Rekayasa Sipil dan Perenc., vol. 2, no. 4, pp. 360-369, 2019.

[14] S. A. Salamah and R. Kusumaningtias, "PENGARUH CORPORATE GOVERNANCE DAN MANAJEMEN RISIKO TERHADAP ISLAMICITY PERFORMANCE INDEX PADA BANK UMUM SYARIAH TAHUN 2014-2018 AKUNESA : Jurnal Akuntansi Unesa," Akunt. Unesa, vol. 8, no. 1, 2019.

[15] R. U. Fahadha, T. Nuryati, and S. Sutarto, "Evaluasi Risiko Rantai Pasok pada Komoditas Bawang Merah di Lampung," Opsi, vol. 12, no. 2, p. 108, 2019.

[16] A. Ridwan, D. L. Trenggonowati, and V. Parida, "Usulan Aksi Mitigasi Risiko Rantai Pasok Halal Pada Ikm Tahu Bandung Sutra Menggunakan Metode House of Risk," J. Ind. Serv., vol. 5, no. 1, pp. 112-120, 2019.

[17] H. M. Naibaho and A. Susanty, "Analisis Penyebab Produk Cacat Pada Bagian Foundry Dengan Metode Failure Mode And Effect Analysis (FMEA)," Ind. Eng. Online, vol. 7, no. 4, 2019. 